\title{
Identifikasi Potensi Perikanan Air Tawar di Desa Perigi Landu Kecamatan Sejangkung Kabupaten Sambas
}

\section{Identifying Potential Freshwater Fisheries in The Perigi Landu Sejangkung District Sambas Regency}

\author{
Uray Windi $^{1}$, Nur Istiqamah ${ }^{1^{*}}$, Muslimah $^{1}$
}

${ }^{1}$ Politeknik Negeri Sambas

Info Artikel:

Diterima : Feb 2021

Disetujui : Mar 2021

Dipublikasi : Mar 2021

\section{Kata Kunci:}

Air Tawar, Perigi Landu, Potensi, Perikanan

\section{Keywords:}

Freshwater, Perigi Landu, Potential, Fisheries

*Korespondensi:

nur istiqamah83@yahoo.com

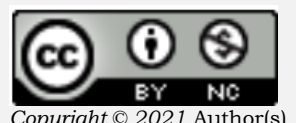

http:// ois. poltesa.ac.id/index.php/nekton

\begin{abstract}
Abstrak. Identifikasi potensi suatu wilayah dapat menjadi pemacu pertumbuhan dan dapat mendorong wilayah lain untuk mengembangkan perikanan tangkap perairan umum atau berkembangnya sektor lain yang dapat berdampak pada terciptanya lapangan pekerjaan. Tujuan dalam penelitian ini untuk mengetahui seberapa besar potensi hasil produksi perikanan tangkap yang dilakukan oleh nelayan perairan umum daratan yang ada di Desa Perigi Landu Kecamatan Sejangkung Kabupaten Sambas. Motode dalam penelitian ini adalah penelitian deskriptif kuantitatif karena dalam pelaksaannya meliputi data dan analisis data. Terdapat 25 sampel dalam penelitian ini kemudian di analisis menggunakan teknik analisis Location Quotient (LQ). Hasil penelitian ini menujukkan bahwa sektor di Desa Perigi Landu Kecamatan Sejangkung Kabupaten Sambas sektor perikanan tangkap perairan umumnya berpotensi karena memiliki sektor unggulan yang mendapatkan nilai $\mathrm{LQ}>1$ atau mendapatkan hasil analisis sebesar 3,05.
\end{abstract}

Abstract. Identifying the potential of a region can act as a catalyst for growth and encourage others to develop fisheries on public waters or expand other sectors that could impact the creation of employment. The goal of this study is to find out how much potential the production of captured fisheries is done by the Perigi Landu of Sejangkung district Sambas regency. The method in this study is a quantitative descriptive study because it covers data and data analysis. There are 25 samples in the study than in the analysis using the location quotient analysis technique (LQ). According to the result of this study, the sector in the Perigi Landu Sejangkung district Sambas regency fisheries sector capture water is generally potentially due to having a quality sector $>1$ or getting a 3.05 .

\section{PENDAHULUAN}

Perikanan adalah semua kegiatan yang berhubungan dengan ikan, termasuk didalamnya memproduksi ikan, baik pada kegiatan penangkapan (perikanan tangkap) maupun budidaya atau pengelolaan yang nantinya untuk memenuhi kebutuhan manusia akan pangan yang sebagai sumber protein dan non-pangan sebagai (pariwisata, ikan hias, dan lain-lain). Ekosistem perairan air tawar dibedakan menjadi dua jenis, yaitu ekosistem perairan air tawar alami dan ekosistem perairan air tawar buatan. Sungai dan danau merupakan contoh ekosistem perairan air tawar alami sedangkan waduk, kolam, dan tambak merupakan contoh ekosistem perairan air tawar buatan. Berdasarkan habitatnya, ekosistem air tawar dibedakan menjadi 
dua, yaitu ekosistem air tawar mengalir (lotik) misalnya sungai dan tergenang (lentik) misalnya waduk (Trimulya 2013).

Perikanan darat merupakan usaha pemeliharaan dan penangkapan ikan di perairan darat. Perairan darat meliputi sungai, danau, rawa, bendungan, sawah, dan tambak. Perikanan darat dibagi menjadi dua jenis yaitu perikanan air payau dan perikanan air tawar. Perikanan air tawar ialah perikanan yang dapat dilakukan di sawah (minapadi), sungai, danau, kolam ataupun di rawa. Keberhasilan budidaya ikan air tawar ditentukan oleh lingkunganya yaitu tanah dan air. Faktor keberhasilan budidaya air tawar ditentukan oleh kualitas tanahnya, tanah yang baik untuk budidaya air tawar adalah jenis tanah liat, jenis tanah ini sangat cocok untuk pembuatan kolam. Tidak hanya tanah, air juga mempunyai peran penting karena air sebagai media ikan untuk hidup.

Ikan air tawar adalah jenis ikan yang melakukan atau sebagian hidupnya di habitat air tawar. Habitat air tawar yang banyak dijadikan tempat untuk ikan tinggal ikan-ikan air tawar adalah sungai, danau, lebak, lebung dan rawa-rawa atau habitat lainnya yang digolongkan sebagai perikanan air tawar dengan garam di bawah 0,5 ppt. Ikan air tawar beradaptasi secara fisiologis terhadap perbedaan tekanan osmosis tubuh dan perairan tawar dengan mengatur keseimbangan konsentrasi elektrolit di dalam tubuhnya (Anggraeni et al., 2015).

Perigi Landu merupakan desa yang terletak di Kecamatan Sejangkung Kabupaten Sambas. Desa Perigi Landu terdiri dari dua dusun yaitu, Semayang dan Lirang, jumlah penduduk di desa ini sebanyak 1.280 jiwa $/ \mathrm{km}^{2}$ (BPS, 2018). Desa Perigi Landu memiliki potensi dari hasil produksi perikanan tangkap perairan umumnya dengan memiliki beberapa jenis ikan unggulan yang mempunyai nilai ekonomis yang tinggi, diantaranya ikan baung, lais, betok, seluang, gabus, lele sungai dan udang galah.

Selama ini pemerintah hanya melirik di bidang perikanan air lautnya saja, padahal jika dilihat perikanan air tawar juga memiliki potensi yang besar. Potensi perikanan air tawar yang dapat dikembangkan meliputi, perikanan tangkap perairan umum daratan, budidaya air tawar maupun pengolahan. Penelitian ini penting dilakukan karena, dengan dilakukannya identifikasi potensi suatu wilayah dapat menjadi pemacu pertumbuhan dan dapat mendorong wilayah lain untuk mengembangkan perikanan tangkap perairan umum atau berkembangnya sektor lain yang dapat berdampak pada terciptanya lapangan pekerjaan.

\section{METODE PENELITIAN}

Penelitian ini dilaksanakan mulai bulan Maret sampai dengan Agustus 2020. Lokasi penelitian dilaksanakan di Desa Perigi Landu Kecamatan Sejangkung Kabupaten Sambas. Jarak dari Kota Sambas ke lokasi penelitian

Windi, U., Istiqamah, N., \& Muslimah. (2021). Identifikasi Potensi Perikanan Air Tawar Di Desa Perigi Landu Kecamatan Sejangkung Kabupaten Sambas. NEKTON: Jurnal Perikanan Dan Ilmu Kelautan, 1(1), 36-43. 
memerlukan waktu 20 menit, jarak dapat ditempuh dengan mengendari transportasi darat yaitu sepeda motor.

Penelitian ini menggunakan jenis penelitian deskriptif dengan metode kuantitatif. Jenis penelitian yang digunakan untuk penelitian ini adalah penelitian deskriptif yang dimana untuk mengambarkan variabel dari potensi perikanan tangkap perairan umum daratan, mulai dari hasil produksi, jenis ikan unggulan, sarana dan prasarana hingga pemasarannya. Penelitian deskriptif yaitu, penelitian yang dilakukan untuk mengetahui nilai variabel mandiri, baik satu variabel atau lebih (independen) tanpa membuat perbandingan, atau menghubungkan dengan variabel lainnya.

Metode penelitian yang digunakan untuk penelitian ini adalah metode kuantitatif. Menurut Sugiyono (2012) metode kuantitatif merupakan metode penelitian yang berdasarkan pada filsafat positivisme, digunakan untuk meneliti pada populasi atau sampel tertentu, pengumpulan data menggunakan instrument penelitian, analisis data bersifat statistik deskritif, yang dimana dalam penelitian ini untuk mengambarkan data yang bersifat statistik mulai dari data hasil produksi, jenis ikan unggulan, sarana dan prasarana hingga pemasarannya dengan tujuan untuk menguji hipotesis yang telah ditetapkan.

Menurut Sugiyono (2012) sampel adalah bagian dari jumlah dan karakteristik yang dimiliki oleh populasi tersebut. Bila populasi besar, dan peneliti tidak mungkin mempelajari semua yang ada pada populasi. Penelitian ini sampel yang diambil adalah 25 orang yaitu keseluruhan dari populasi karena populasi yang ada dalam jumlah yang kecil. Hal ini sering dilakukan bila jumlah populasinya relatif kecil, kurang dari 30 orang. Sampel jenuh disebut juga dengan istilah sensus, dimana semua anggota populasi dijadikan sampel (Sugiyono 2017).

Variabel adalah segala sesuatu yang berbentuk apa saja yang ditetapkan oleh peneliti untuk mempelajari sehingga memperoleh informasi tentang hasil tersebut, kemudian ditarik kesimpulannya (Sugiyono 2017). Variabel dalam penelitian ini adalah potensi hasil produksi perikanan tangkap perairan umum di Desa Perigi Landu Kecamatan Sejangkung tahun 2020. Skala merupakan teknik pengumpulan data yang bersifat mengukur, karena diperoleh dari hasil ukur yang berbentuk angka-angka. Skala pengukuran yang digunakan untuk mengukur potensi hasil produksi perikanan tangkap perairan umum dalam penelitian ini adalah skala nominal.

\section{Teknik Analisis Data}

Metode analisis data yang digunakan ialah analisis Location Quotient (LQ). Metode LQ merupakan salah satu pendekatan yang umum digunakan dalam model ekonomi basis sebagai langkah awal untuk memahami sektor kegiatan dari PDRB Desa Perigi Landu Kecamatan Sejangkung yang menjadi

Windi, U., Istiqamah, N., \& Muslimah. (2021). Identifikasi Potensi Perikanan Air Tawar Di Desa Perigi Landu Kecamatan Sejangkung Kabupaten Sambas. NEKTON: Jurnal Perikanan Dan Ilmu Kelautan, 1(1), 36-43. 
pemacu pertumbuhan. Untuk mendapatkan nilai LQ menggunakan metode yang mengacu pada formula yang dikemukakan oleh Bendavid-Val dalam Kuncoro (2004) sebagai berikut:

$\frac{\frac{X r}{R V r}}{\frac{X n}{R V n}}$

Ket:

$\mathrm{Xr} \quad$ : Jumlah produksi sektor $i$ kecamatan

$\mathrm{Xn} \quad$ : Jumlah produksi sektor $i$ provinsi

RVr : Jumlah produksi total sektor kabupaten

RVn : Jumlah produksi total sektor provinsi

Hasil perhitungan LQ menghasilkan tiga (3) kriteria, yaitu:

1. LQ > 1: sektor itu menjadi basis atau menjadi sumber pertumbuhan. Sektor memiliki keunggulan komparatif, hasilnya tidak saja dapat memenuhi kebutuhan di wilayah bersangkutan akan tetapi juga dapat diekspor ke luar wilayah.

2. $\mathrm{LQ}=1$ : sektor itu tergolong non basis, tidak memiliki unggulan komparatif, produksinya hanya cukup memenuhi kebutuhan sendiri dan tidak mampu untuk memenihi kebutuhan luar wilayah

3. LQ < 1: sektor ini juga termasuk non basis. Produksi di suatu wilayah tidak dapat memenuhi kebutuhan sendiri sehingga perlu pasokan dari luar wilayah.

\section{HASIL DAN PEMBAHASAN}

Nelayan perikanan tangkap perairan umum di Desa Perigi Landu ada 25 orang, pengalaman menjadi nelayan paling lama baru 4 tahun, dapat dikatakan baru, karena baru 4 tahun terakhir diberikan bantuan oleh pemerintah dan barulah di bentuk dalam satu kelompok. Pemerintah memberikan bantuan berupa bahan untuk membuat alat tangkap seperti jala, pukat dan bubu. Menjadi nelayan perairan umum merupakan perkerjaan utama responden dalam penelitian ini, walaupun hasil dari menjual tangkapan ikan belum cukup untuk memenuhi kebutuhan seharihari. Untuk menambah pemasukan, nelayan di Desa Perigi Landu memiliki pekerjaan sampingan yaitu sebagai petani padi dan ada juga yang menjadi buruh bangunan.

Berdasarkan ikan yang dijual oleh nelayan perairan umum dapat dilihat bahwa jenis ikan yang didapatkan oleh nelayan memiliki nilai ekonomis tinggi dan bernilai ekonomis, adapun jenis ikannya adalah Baung, 
Lais, Gabus, dan Udang galah yang dimana jenis ini memiliki nilai ekonomis tinggi sedangkan jenis ikan seperti Seluang, Betok dan Lele Sungai yang dimana jenis ikan ini termasuk dalam jenis ikan yang bernilai ekonomis. Desa Perigi Landu memiliki ikan yang berpotensi untuk dikembangkan dari beberapa jenis ikan unggulan ada dua jenis ikan yang berpotensi untuk dikembangkan yaitu ikan baung dan lais, karena dua jenin ikan ini yang paling sering didapatkan oleh nelayan dan ikan ini juga memiliki harga yang tinggi untuk di pasarkan.

Nelayan perikanan tangkap umum daratan di Desa Perigi Landu memiliki hasil tangkapan yang beragam mulai dari $2 \mathrm{~kg}$ sampai dengan $5 \mathrm{~kg}$ perharinya. Waktu yang dipilih nelayan perairan umum untuk melakukan usaha perikanan tangkap ada dua waktu yaitu pada pagi hari dan malam hari. Nelayan perairan umum melakukan usaha perikanan tangkap setiap hari dengan lama waktu sekali perjalanan bermacam-macam mulai dari 6 jam sampai dengan 9 jam. Untuk jarak tempuh menangkap ikan nelayan perairan umum di Desa Perigi Landu memiliki tiga macam yaitu jarak tempuh yang paling dekat hanya $1 \mathrm{~km}$ sampai $1,5 \mathrm{~km}$ sedangkan untuk jarak tempuh paling jauh yang dilakukan oleh nelayan perairan umum hanya $2 \mathrm{~km}$.

Nelayan perairan umum di Desa Perigi Landu memiliki sarana dan prasaran yang membantu untuk muwujudkan nelayan mencapai tujuannya. Sarana yang digunakan nelayan perairan umum didalam penelitian ini ada dua jenis, yang pertama menggunakan sarana perahu motor yang dimana perahu ini memiliki ukuran yang sedang dan mesin yang digunakan untuk perahu motor ini adalah jenis mesin ukuran 3,3 pk. Nelayan yang memiliki sarana perahu motor hanya 20 orang dari 25 responden. Sarana yang kedua yang digunakan nelayan untuk melakukan usaha perikanan tangkap adalah sampan dalam penelitian ini sampan yang digunakan berukuran kecil dan hanya dibantu oleh dayung untuk bisa menjalankan sampannya. Nelayan didalam penelitian ini yang memiliki sarana sampan berjumlah 5 orang dari 25 responden.

Prasarana yang digunakan nelayan didalam penelitian ini ada beberapa jenis alat tangkap diantarannya Jala, Bubu, Pukat, Tombak dan Pancingan, serta bahan bakar untuk nelayan yang sarananya menggunakan perahu motor. Bahan bakar yang nelayan gunakan dalam penelitian ini adalah bensin, satu kali perjanan biasanya hanya memerlukan satu liter bensin yang dimana satu liter bensin dapat menempuh jarak $\pm 2 \mathrm{~km}$. nelayan mendapatkannya dengan cara membeli di kios terdekat.

Alat tangkap yang digunakan nelayan dapatkan dengan cara membeli dan membuat sendiri, adapun alat tangkap yang dibuat oleh nelayan perairan umum di Desa Perigi Landu yang pertama alat tangkap bubu, yang dimana alat tangkap ini terbuat dari bambu yang dipotong- potong sesuai dengan ukuran yang diinginkan, lalu bambu yang sudah dipotong selanjutnya disusun sehingga membentuk seperti tabung selanjutnya diikat supaya 
bambu tidak berantakan. Setelah itu membuat penutup alat tangkap bubu yang dimana terbuat dari bambu yang dianyam. Proses pembuatan bubu hanya memerlukan waktu 1 hari saja. Bubu yang digunakan oleh nelayan di Desa Perigi Landu berbentuk seperti tabung dengan ukuran kurang lebih 1 meter, bubu biasanya dibiarkan semalaman di spot yang sudah ditentukan oleh nelayan dan keesokan harinya bubu akan diambil kembali. Alat tangkap bubu ini dapat menangkap ikan jenis seperti baung dan lais tetapi tidak menutup kemungkinan jenis ikan lainnya dapat ditangkap menggunakan alat ini.

Alat tangkap yang kedua alat tangkap tombak yang dimana alat tangkap dalam penelitian ini terbuat dari besi payung yang dibentuk bermata empat dan pada bagian ganggang pegangan biasanya nelayan membuatnya dari bamboo berukuran sedang dengan panjang kurang lebih 1 sampai 1,5 meter. Alat tangkap tombak biasanya digunakan untuk menangkap ikan gabus, betok dan lele sungai. Alat tangkap yang ketiga ada Pancingan, pancingan yang digunakan nelayan dalam penelitian ini ada dua jenis yaitu pancingan yang terbuat dari bahan plastik atau besi yang biasanya didapat dengan cara membeli di pasar. Jenis pancingan yang kedua nelayan dapatkan dengan cara membuat sendiri dengan bambu ukuran kecil dan selanjutnya diberi tali dan diberi mata pancing. Alat tangkap pancing dapat digunakan untuk menangkap ikan baung, lais, dan udang galah tidak hanya alat tangkap bubu tetapi dengan pancingan juga bisa mendapatkan ikan baung dan lais. Alat tangkap jala dan pukat biasanya digunakan untuk menangkap ikan seluang, baung, dan lais serta ikan lainya.

Pemasaran dalam penelitian ini langsung dilakukan setelah nelayan pulang dari menangkap ikan. Pemasaran hasil tangkapan dilakukan sendiri oleh nelayan, hasil tangkapan di pasarkan di sekitar Desa Perigi Landu. Alasan nelayan dalam penelitian ini memasarkan hasil tangkapannya sendiri karena ingin mengurangi biaya upah pemasaran sehingga hasil penjualan hasil tangkapan tidak perlu dibagi dengan jasa pemasar ikan. Harga ikan yang dipasarkan oleh nelayan beragam seperti ikan baung, lais dan gabus harga jualnya Rp. 40.000/kg, ikan lele sungai dan ikan seluang nelayan menjual dengan harga yanng cukup murah yaitu Rp. 25.000/kg nya, untuk ikan betok hanya Rp. 30.000/kg. Tidak hanya ikan nelayan juga menjual udang galah hasil tangkapan, untuk udang galah grade A nelayan menjual dengan harga Rp. $110.000 / \mathrm{kg}$ nya, biasanya dalam satu kilogram udang galah hanya dapat tiga sampai empat ekor saja. Untuk udang galah grade B bisa didapatkan dengan harga Rp. $80.000 / \mathrm{kg}$ nya, dan untuk grade C nelayan hanya menjual Rp. 60.000/kg.

Kendala yang ditemukan di dalam penelitian ini adalah penurunan jumlah tangkapan nelayan yang disebabkan karena tercemarnya air di Sungai oleh limbah dari pabrik kelapa sawit, pada tahun 2019 lalu ribuan ikan mati di Sungai karena tercemarnya air Sungai. Nelayan juga mengeluh 
karena pendapatan hasil tangkapan ikan menjadi berkurang. Awalnya nelayan perairan umum daratan di Desa Pergi Landu mendapatkan hasil tangkapan yang cukup banyak perharinya yaitu sebanyak $40 \mathrm{~kg}$ per hari.

\section{Location Qoutient}

Data-data yang didapatkan dari responden dan dari berbagai lembaga terkait data hasil produksi perikanan tangkap perairan umum di Kabupaten Sambas dan Provinsi Kalimantan Barat secara jelas dapat dilihat pada Tabel 1 berikut:

Tabel 1. Data hasil produksi perikanan tangkap perairan umum

\begin{tabular}{|c|c|c|}
\hline Keterangan & $\begin{array}{c}\text { Jumlah } \\
\text { produksi/tahun }\end{array}$ & Sumber data \\
\hline $\begin{array}{l}\text { Jumlah produksi sektor } \\
i \text { kecamatan }\end{array}$ & 30,96 ton & Data hasil wawancara dengan responden \\
\hline $\begin{array}{l}\text { Jumlah produksi sektor } \\
i \text { provinsi }\end{array}$ & 34.305 ton & $\begin{array}{l}\text { Direktorat Jenderal Perikanan Tangkap, } \\
\text { diakses melalui https://www.bps.go.id/ }\end{array}$ \\
\hline $\begin{array}{l}\text { Jumlah produksi total } \\
\text { sektor kabupaten }\end{array}$ & 138,6 ton & $\begin{array}{l}\text { Data hasil wawancara di Dinas } \\
\text { Periknana, Peternakan dan Kesehatan } \\
\text { Hewan Kabupaten Sambas }\end{array}$ \\
\hline $\begin{array}{l}\text { Jumlah produksi total } \\
\text { sektor provinsi }\end{array}$ & 467.822 ton & $\begin{array}{l}\text { Direktorat Jendral Perikanan Tangkap, } \\
\text { diakses melalui https://www.bps.go.id/ }\end{array}$ \\
\hline
\end{tabular}

Hasil Analisis LQ menurut Hasil Produksi Perikanan Tangkap Perairan Umum Daratan di Desa Perigi Landu Kecamatan Sejangkung Kabupaten Sambas tahun 2020 secara jelas dapat dilihat dari hasil perhitungan berikut:

$$
\begin{gathered}
L Q=\frac{\frac{30,96}{138,6}}{\frac{34.205}{467.822}} \\
L Q=\frac{0,2234}{0,0731} \\
L Q=3,05
\end{gathered}
$$

Berdasarkan hasil perhitungan analisis LQ menggunakan data hasil produksi perikanan tangkap perairan umum daratan di Kecamatan Sejangkung terhadap produksi perikanan tangkap perairan umum daratan di Kabupaten Sambas dapat dilihat bahwa hasil produksi perikanan tangkap perairan umum daratan memiliki potensi yang cukup besar untuk melayani pasar di daerah maupun di luar daerah hal ini terlihat dari hasil perhitungan analisis LQ yang mencapai > 1, sehingga nelayan perikanan tangkap perairan 
umum daratan di Desa Perigi Landu harus mengembangkan usaha perikanan tangkap perairan umumnya.

\section{KESIMPULAN}

Berdasarkan hasil pengolahan data dan analisis data yang telah dilakukan dapat ditarik kesimpulan bahwa analisis Location Quotient (LQ) di Desa Perigi Landu dapat dikatakan wilayah berpotensi karena memiliki sektor unggulan, yang dimana hasilnya tidak saja dapat memenuhi kebutuhan di wilayah bersangkutan akan tetapi juga dapat diekspor ke luar wilayah.

\section{DAFTAR PUSTAKA}

Anggraeni, D.T., Qomariyah, Q., \& Khalidah, K. (2015). Penyebaran dan Budidaya Ikan Air Tawar di Pulau Jawa Berbasis Web. Prosiding SNST Fakultas Teknik, 1(1), 101-105.

Badan Pusat Statistik. (2018). Kecamatan Sejangkung Dalam Angka 2018. BPS Sambas. Kalimantan Barat.

Kuncoro, M. (2004). Otonomi dan Pembangunan Daerah. Erlangga. Jakarta Sugiyono. (2012). Metode Penelitian Kuantitatif Kualitatif dan R\&D. Alfabeta. Bandung

Sugiyono. (2017). Metode Penelitian Kuantitatif, Kualitatif, dan R\&D. Alfabeta. Bandung

Trimulya, D. (2013). Ekologi Perairan Tergenang di Wilayah Waduk Ciwaka Walantaka. Jurnal Ekologi Perairan, 1(1), 1-9. 